\title{
Effect of different dosages of oregano oil on performance and some blood parameters in lambs"
}

\author{
Aylin ÜNAL ${ }^{1}$, Neșe KOCABAĞLI ${ }^{2}$ \\ ${ }^{1}$ Kartal Kimya San. ve Tic. A.Ş., Gebze, Kocaeli; ${ }^{2}$ Department of Animal Nutrition and Nutritional Diseases, Istanbul University, \\ Veterinary Faculty, Avcilar, Istanbul, Turkey.
}

\begin{abstract}
Summary: This research was carried out to determine whether adding oregano essential oil as a feed additive to the diet would affect the performance, carcass characteristics and some blood parameters of lambs. In the trial, 36 weaned male Kivircik lambs (2.5-3 month-old) were used. Lambs had an initial live weight of 22,71 $\pm 0,71 \mathrm{~kg}$ and were divided into three groups of 12 lambs each. For the two treatment groups, Origanum vulgare essential oil was added into grower feed at the dose of $250 \mathrm{ppm}$ and $500 \mathrm{ppm}$ respectively. Besides this, hay was provided as roughage. Feed and water was supplied ad libitum during the trial. The first week was accepted as adaptation period and the experiment lasted for 9 weeks. The live weights and feed consumptions were measured in the beginning of the experiment and on the $14,28,42$ and $56^{\text {th }}$ days. Blood samples were collected before the morning feeding on the 0,28 and $56^{\text {th }}$ days of the experiment. All lambs were slaughtered, hot carcass weights and the weights of liver, empty stomach and empty intestine were determined at the end of the experiment. Serum concentrations of total cholesterol, triglyceride, high density lipoprotein (HDL) and low density lipoprotein (LDL) were measured using commercial kits. The final live weights were $28 \pm 0,73 \mathrm{~kg}$ and no differences were observed among treatments. Daily live weight gain, hot carcass weights and yields, organ weights and serum parameters were not statistically significant between groups $(\mathrm{P}>0.05)$. In conclusion, addition of the oregano oil had no significant effects on performance, organ weights and blood parameters of weaned lambs in this study.
\end{abstract}

Key words: Blood parameters, fattening performance, lamb, oregano oil.

\section{Yeme farklı düzeylerde katılan kekik yağının kuzularda besi performansı ve bazı kan parametreleri üzerine etkisi}

Özet: Bu araştırma, rasyona katılan kekik yağının, kuzuların performans, karkas özellikleri ve bazı kan parametreleri üzerine olan etkilerinin saptanması amacıyla yapılmıştır. Araştırmada, 36 baş sütten kesilmiş erkek Kıvırcık 1rkı kuzu (2,5-3 aylık) kullanılmıştır. Başlangıç canlı ağırlıkları 22,71 $\pm 0,71 \mathrm{~kg}$ olan kuzular, her birinde 12 baş olacak şekilde üç gruba ayrılarak, deneme gruplarından birinin kuzu büyütme yemine 250 ppm, diğerine ise 500 ppm kekik yağı (Origanum vulgare) eklenmiştir. Bunun yanında kaba yem olarak kuru ot verilmiştir. Deneme süresince yem ve su ad libitum olarak verilmiştir. Deneme, ilk haftası adaptasyon dönemi olmak üzere, toplam 9 hafta sürdürülmüştür. Hayvanların canlı ağılıkları ve yem tüketimleri denemenin başlangıcında, 14, 28, 42 ve 56. günlerde ölçülmüştür. Kan örnekleri, denemenin 0., 28. ve 56. günlerinde sabah yemlemesinden önce alınmıştır. Deneme sonunda bütün kuzular kesilip sıcak karkas ağırlıkları ile karaciğer, boş mide, boş bağırsak ağırlıkları ölçülmüştür. Kan örneklerinden, ticari kitler yardımıyla total kolesterol, trigliserit, HDL ve LDL analizleri yapılmıştır. Besi sonu canlı ağırlıkları $28 \pm 0,73 \mathrm{~kg}$ olarak bulunmuş olup, gruplar arasında bir farklılık saptanmamıştır. Günlük canlı ağırlık artışları, sıcak karkas ağırlıkları ve verimleri, organ ağırlıkları ile serum parametreleri bakımından gruplar arasında istatistik önemde bir farklılık bulunmamıştır $(\mathrm{P}>0,05)$. Buna göre sütten yeni kesilmiş kuzularda rasyona kekik yağı katılmasının, besi performansı, organ ağırlıkları ve kan parametreleri üzerinde önemli bir farklılık oluşturmadığı saptanmıştır.

Anahtar sözcükler: Besi performansı, kan parametreleri, kekik yağı, kuzu.

\section{Introduction}

In recent years alternative feed additives were researched instead of antibiotics, and as a result probiotics, organic acids and plant extracts have gained interest as natural growth promoters in this regard (5). In Turkey the use of plant extracts in animal nutrition is growing as well as all over the world, because their consumption by human and animals are recognized as safe (18), and they have many beneficial effects. There is limited research data and also conflicting findings about this subject in ruminants $(2,3,9)$. Bampidis et al. (2) found that adding oregano essential oil at levels of 144

\footnotetext{
* This study is summarized from the doctoral thesis (supported by Istanbul University Research Fund with the project number T2418). The thesis was done in accordance with the ethical regulations.
} 
ppm and 288 ppm of concentrate did not make any difference on average daily gain and feed conversion ratio (FCR) of lambs. Yet these lambs gained weight regularly during the trial and the rate of live weight gain had a similarity with the increasing dosages of oregano. It was reported that an essential oil mixture which consists of thymol, eugenol, vanillin and limonene active substances improved feed conversion ratio of beef cattle, supplemented at a dose of $2 \mathrm{~g}$ /day (3). Contrary to this, feeding of $250 \mathrm{mg}$ /day of oregano oil to sheep did not influence feed intake (24) and feeding oregano oil up to 5 $\mathrm{g} / \mathrm{kg}$ dry matter (DM) to lambs had no positive effect on fattening performance (7).

The objective of this study reported herein was to determine the effects of oregano oil which is produced in Turkey and added in different doses into lamb feed, on the performance as well as some blood parameters of lambs.

\section{Materials and Methods}

In this research, 36 weaned male Kivircik lambs with an initial live weight of $22,71 \pm 0,71 \mathrm{~kg}$ obtained from the research farm of Istanbul University were used as animal material. Conformity of the study with the principles of ethical committee was approved by Istanbul University Local Ethical Committee on Animal Testing. The study was carried out in the small animal boxes in size of $4,0 \mathrm{~m} \times 3,0 \mathrm{~m}$ in the clinics of the veterinary faculty. The study lasted for 9 weeks including one week adaptation period. At the end of adaptation period, live weights of the lambs was recorded and they were randomized in three groups, two treatment groups and one control group each of which consists of 12 lambs. During the study, hay was used as forage and lamb grower feed was used as concentrate pellets. Concentrate feed was specially produced on a monthly basis in a factory, in order to prevent the spoiling of oregano oil while it was stored. The oregano oil was added into lamb grower feed of two treatment groups, for the first treatment group $250 \mathrm{ppm}$, and $500 \mathrm{ppm}$ for the second treatment group. The oregano oil used in the study, was provided from a commercial company in Turkey and analyzed in BIBAM Laboratory of Anadolu University and it was reported that analyzed material contained $65 \%$ carvacrol and $0,3 \%$ thymol. Feed ingredients were formulated by regarding survival rate and performance rate for weaned lambs and in accordance with nutrient and energy requirements specified by NRC (15). In the study, group feeding method was used and a diet consisting of $40 \%$ hay $+60 \%$ concentrate pellets (metabolizable energy $(\mathrm{ME})=2,65 \mathrm{Mcal} / \mathrm{kg}$ ) and $\mathrm{ad}$ libitum water were offered. Dry matter, crude ash, crude protein, crude fat (ether extracts) and crude cellulose contents of lamb grower feed and hay were analyzed in accordance with Weende Analysis System, colorimetric calcium level analysis and spectophotometric phosphorus level analysis were performed in the laboratory of Animal Nutrition and Nutritional Diseases department (1). Acid detergent fiber (ADF) and neutral detergent fiber (NDF) analyses were performed by using cellulose assay device (Table-1).

Table 1. Ingredients and chemical composition of diets used in the current experiment (Dry Matter, \%).

Tablo 1. Deneme yeminin içeriği ve kimyasal kompozisyonu (Kuru Maddede, \%).

\begin{tabular}{|c|c|c|c|c|}
\hline \multirow[t]{2}{*}{ Feedstuffs, \% } & \multicolumn{3}{|c|}{ Lamb Grower Feed } & \\
\hline & Control & $\begin{array}{c}250 \mathrm{ppm} \\
\text { Oo }\end{array}$ & $\begin{array}{l}500 \mathrm{ppm} \\
\text { Oo }\end{array}$ & \\
\hline Barley & 19,40 & 19,40 & 19,40 & \\
\hline Corn & 11,30 & 11,30 & 11,30 & \\
\hline Corn Gluten & 8,50 & 8,50 & 8,50 & \\
\hline Wheat Bran & 31,80 & 31,80 & 31,80 & \\
\hline Soybean Meal & 6,50 & 6,50 & 6,50 & \\
\hline Sunflower Meal & 13,90 & 13,90 & 13,90 & \\
\hline Molasses & 5,10 & 5,10 & 5,10 & \\
\hline $\mathrm{CaCO}_{3}$ & 2,85 & 2,85 & 2,85 & \\
\hline Salt & 0,54 & 0,54 & 0,54 & \\
\hline Mineral Premix ${ }^{1}$ & 0,10 & 0,10 & 0,10 & \\
\hline Vitamin Premix ${ }^{2}$ & 0,01 & 0,01 & 0,01 & \\
\hline $\begin{array}{l}\text { Nutrient } \\
\text { Composition, \% }\end{array}$ & Control & $\begin{array}{c}250 \mathrm{ppm} \\
\text { Oo }\end{array}$ & $\begin{array}{l}500 \mathrm{ppm} \\
\text { Oo }\end{array}$ & Hay \\
\hline Dry Matter & 87,30 & 87,22 & 87,36 & 93,40 \\
\hline Crude Protein & 17,86 & 17,63 & 17,83 & 8,89 \\
\hline Crude Fat & 3,55 & 3,81 & 3,92 & 0,95 \\
\hline Crude Cellulose & 5,13 & 5,03 & 5,21 & 40,32 \\
\hline Crude Ash & 6,15 & 6,01 & 6,22 & 7,79 \\
\hline NDF & 19,56 & 19,57 & 19,57 & 60,95 \\
\hline $\mathrm{ADF}$ & 7,83 & 7,84 & 7,84 & 43,04 \\
\hline Calcium & 1,05 & 1,10 & 1,08 & 1,31 \\
\hline Phosphorus & 0,54 & 0,52 & 0,53 & 0,20 \\
\hline
\end{tabular}

$1 \mathrm{~kg}$ premix contained $10.000 \mathrm{mg} \mathrm{Cu}, 50.000 \mathrm{mg} \mathrm{Fe}, 50.000$ $\mathrm{mg} \mathrm{Mn}, 50.000 \mathrm{mg} \mathrm{Zn,} 50 \mathrm{mg} \mathrm{Co,} 800 \mathrm{mg} \mathrm{I}, 150 \mathrm{mg} \mathrm{Se}$, $340.000 \mathrm{mg} \mathrm{Ca}$.

$21 \mathrm{~kg}$ premix contained 66.700.000 IU Vitamin A, 16.700.000 IU Vitamin D3, 167.000 IU $\alpha$-tocopherol acetate, $42.000 \mathrm{mg}$ Vitamin $B_{1}, 25.000 \mathrm{mg}$ Vitamin $B_{2}, 125 \mathrm{mg}$ Vitamin $B_{12}$, $12.5000 \mathrm{mg}$ Niacin

Oo: Oregano oil

Animals were weighed before morning feeding in the beginning and on the $14,28,42$ and $56^{\text {th }}$ days of the trial. At the end of the trial, feed consumption and feed conversion ratios of each group were calculated. On the 0,28 and $56^{\text {th }}$ days of the trial, blood was collected before morning feeding from the Vena Jugularis of all lambs into $10 \mathrm{ml}$ vacuum tubes by using cannula. Blood samples were centrifuged at $3000 \mathrm{rpm}$ for 5 minutes, and 
extracted blood serum samples were stored in ependorf tubes in deep freeze at $-18^{\circ} \mathrm{C}$ temperature until the date of analysis. By using commercial test kits serum cholesterol, triglyceride, HDL and LDL levels of blood serum samples were measured. At the end of the study, all of the lambs were slaughtered in the slaughterhouse of the faculty. After dissection of head, skin, feet and inner organs, hot carcass weights were recorded. Weight of liver, empty stomach and empty intestines were weighed by digital scales. One-way variance analysis method was used for the purpose of statistical comparison of the groups regarding live weight levels and daily live weight gains at certain periods of the trial and also slaughtering and carcass characteristics of the lambs. For the purpose of comparison of the groups regarding serum parameters, repeated measures variance analysis method was used. In the statistical model; group was indicated as "betweensubject factor", and measurement time was indicated as "within subject factor". For statistical calculations, SPSS 10.0 software was used (19).

\section{Results}

In the study, statistically significant difference between the groups regarding average live weights and daily live weight gains was not found (Table-2). Because of feeding the lambs totally in groups, no statistical evaluation was performed for feed consumption and FCR (Table-2). At the end of the study, the highest feed consumption was found in the treatment group with 250 ppm oregano oil additive and lowest FCR was found in the control group. No statistically significant difference was found between the groups regarding measured hot carcass weight, hot carcass yields and organ weights of the lambs (Table-3).

It was found that there was not any statistically significant difference between the groups regarding serum total cholesterol, triglyceride, LDL and HDL levels (Table-4). The serum total cholesterol level at day 28 was in all groups significantly lower in comparison with the levels on other measurement days. The difference between serum LDL concentration levels of the control group measured on day 28 and day 56 was statistically significant. However when compared to the initial values it was observed that the difference disappeared. Also the serum LDL concentration levels of both treatment groups, measured on the $28^{\text {th }}$ day were found significantly lower than the levels on other measurement days $(\mathrm{P}<0,01)$. The initial serum HDL concentration level of the group, fed with $250 \mathrm{ppm}$ oregano oil additive was significantly higher than the levels on the other measurement days $(\mathrm{P}<0,001)$ and the serum HDL concentration level of the group, fed with $500 \mathrm{ppm}$ oregano oil additive was found significantly lower on the $28^{\text {th }}$ day, compared to the other measurement days $(\mathrm{P}<0,001)$.

Table 2. The effect of oregano oil on the live weight and feed consumptions of lambs

Tablo 2. Kekik yağının kuzuların canlı ağırlık ve yem tüketimleri üzerine etkisi

\begin{tabular}{|c|c|c|c|c|c|c|c|}
\hline & \multicolumn{6}{|c|}{ Groups } & \multirow[t]{3}{*}{ Significance } \\
\hline & \multicolumn{2}{|c|}{ Control } & \multicolumn{2}{|c|}{250 ppm Oo } & \multicolumn{2}{|c|}{500 ppm Oo } & \\
\hline & $\mathrm{x} \pm$ & Sx & $x \pm$ & $\mathrm{Sx}$ & $\mathrm{x} \pm$ & Sx & \\
\hline \multicolumn{8}{|c|}{$\begin{array}{c}\text { Live Weight, } \mathrm{kg} \\
\text { Days }\end{array}$} \\
\hline 0 & 22,66 & 1,41 & 22,67 & 1,25 & 22,80 & 1,14 & NS \\
\hline 14 & 24,72 & 1,51 & 23,88 & 1,02 & 23,82 & 1,23 & NS \\
\hline 28 & 26,95 & 1,39 & 27,46 & 1,04 & 26,62 & 1,41 & NS \\
\hline 42 & 27,58 & 1,48 & 26,79 & 0,81 & 27,21 & 1,45 & NS \\
\hline 56 & 28,19 & 1,52 & 27,75 & 0,69 & 28,10 & 1,52 & NS \\
\hline \multicolumn{8}{|c|}{$\begin{array}{l}\text { Daily Live Weight Gain, g } \\
\text { Days }\end{array}$} \\
\hline 14 & 146,43 & 26,15 & 86,31 & 29,98 & 73,21 & 21,03 & NS \\
\hline 28 & 152,83 & 14,42 & 170,83 & 17,15 & 136,31 & 12,68 & NS \\
\hline 42 & 117,06 & 9,15 & 98,02 & 15,19 & 104,96 & 10,17 & NS \\
\hline 56 & 98,73 & 7,47 & 90,62 & 12,27 & 94,64 & 7,98 & NS \\
\hline \multicolumn{8}{|c|}{$\begin{array}{l}\text { Total Feed Consumption, kg } \\
\text { Days }\end{array}$} \\
\hline 56 & 65,73 & & 66,30 & & 64,60 & & \\
\hline \multicolumn{8}{|c|}{$\begin{array}{l}\text { Feed Convertion Ratio } \\
\text { Days }\end{array}$} \\
\hline 56 & 11,88 & & 13,05 & & 12,18 & & \\
\hline
\end{tabular}

Oo: Oregano oil

NS: The difference between the mean values is not significant $(\mathrm{P}>0,05)$ 
Table 3. The body weights, hot carcass weights and yields, weights of some organs of the slaughtered lambs at the end of the trial. Tablo 3. Deneme sonunda kesilen kuzuların canlı ağırlıkları, sıcak karkas ağırlıkları ve randımanları ile bazı organ ağırlıkları.

\begin{tabular}{lccccccc}
\hline \multirow{2}{*}{ Item } & \multicolumn{2}{c}{ Control } & \multicolumn{2}{c}{$250 \mathrm{ppm}$ Oo } & \multicolumn{2}{c}{$500 \mathrm{ppm}$ Oo } & \multirow{2}{*}{ Significance } \\
\hline Live Weight, $\mathrm{kg}$ & $\mathrm{x} \pm$ & $\mathrm{Sx}$ & $\mathrm{x} \pm$ & $\mathrm{Sx}$ & $\mathrm{x} \pm$ & $\mathrm{Sx}$ & \\
Hot Carcass Weight, $\mathrm{kg}$ & 27,92 & 1,47 & 27,08 & 0,86 & 27,60 & 1,51 & $\mathrm{NS}$ \\
Hot Carcass Yield, $\%$ & 13,92 & 0,89 & 13,49 & 0,56 & 13,54 & 0,78 & $\mathrm{NS}$ \\
Liver Weight, kg & 49,56 & 0,64 & 49,62 & 0,66 & 48,99 & 0,68 & $\mathrm{NS}$ \\
Empty Stomach Weight, $\mathrm{kg}$ & 0,49 & 0,03 & 0,46 & 0,01 & 0,49 & 0,032 & $\mathrm{NS}$ \\
Empty Intestine Weight, $\mathrm{kg}$ & 0,87 & 0,04 & 0,82 & 0,02 & 0,88 & 0,043 & $\mathrm{NS}$ \\
\hline
\end{tabular}

Oo: Oregano oil

NS: The difference between the mean values is not significant $(\mathrm{P}>0,05)$

Table 4. The effect of oregano oil on serum total cholesterol, triglyceride, LDL and HDL levels, mg/dl. Tablo 4. Kekik yağının serum total kolesterol, trigliserit, LDL ve HDL düzeyleri üzerine etkisi, mg/dl.

\begin{tabular}{|c|c|c|c|c|c|c|c|c|}
\hline & \multirow{2}{*}{ Days } & \multicolumn{3}{|c|}{ Groups } & \multirow[b]{2}{*}{ SEM } & \multicolumn{3}{|c|}{ Significance } \\
\hline & & Control & 250 ppm Oo & 500 ppm Oo & & Group & Time & Group x Time \\
\hline \multirow{4}{*}{ Cholesterol } & 0 & 51,25 & $61,50^{\mathrm{x}}$ & $53,75^{\mathrm{x}}$ & 3,21 & \multirow{4}{*}{ NS } & \multirow{4}{*}{$* * *$} & \multirow{4}{*}{$* *$} \\
\hline & 28 & 47,00 & $35,25^{\mathrm{z}}$ & $31,58^{\mathrm{y}}$ & 4,29 & & & \\
\hline & 56 & 51,33 & $51,17^{\mathrm{y}}$ & $53,50^{\mathrm{x}}$ & 3,46 & & & \\
\hline & & NS & $* * *$ & $* * *$ & & & & \\
\hline \multirow{4}{*}{ Triglyceride } & 0 & $64,17^{\mathrm{x}}$ & $50,75^{\mathrm{x}}$ & $43,67^{\mathrm{x}}$ & 7,52 & \multirow{4}{*}{ NS } & \multirow{4}{*}{$* * *$} & \multirow{4}{*}{ NS } \\
\hline & 28 & $11,33^{\mathrm{y}}$ & $9,75^{\mathrm{y}}$ & $10,58^{\mathrm{y}}$ & 2,86 & & & \\
\hline & \multirow[t]{2}{*}{56} & $2,83^{z}$ & $6,00^{\mathrm{y}}$ & $14,58^{\mathrm{y}}$ & 5,47 & & & \\
\hline & & $* * *$ & $* * *$ & $* *$ & & & & \\
\hline \multirow{4}{*}{ LDL } & 0 & $14,33^{x y}$ & $18,25^{\mathrm{x}}$ & $15,67^{\mathrm{x}}$ & 2,10 & \multirow{4}{*}{ NS } & \multirow{4}{*}{$* * *$} & \multirow{4}{*}{ NS } \\
\hline & 28 & $13,42^{y}$ & $10,17^{\mathrm{y}}$ & $8,67^{\mathrm{y}}$ & 1,69 & & & \\
\hline & \multirow[t]{2}{*}{56} & $18,33^{\mathrm{x}}$ & $17,08^{\mathrm{x}}$ & $14,42^{x}$ & 1,70 & & & \\
\hline & & $*$ & $* *$ & $* *$ & & & & \\
\hline \multirow{4}{*}{ HDL } & 0 & 38,83 & $39,25^{\mathrm{x}}$ & $35,92^{\mathrm{x}}$ & 3,96 & \multirow{4}{*}{ NS } & \multirow{4}{*}{$* * *$} & \multirow{4}{*}{ NS } \\
\hline & 28 & 31,00 & $22,75^{\mathrm{y}}$ & $21,83^{y}$ & 3,04 & & & \\
\hline & 56 & 32,33 & $27,42^{y}$ & $33,75^{\mathrm{x}}$ & 1,83 & & & \\
\hline & & NS & $* * *$ & $* * *$ & & & & \\
\hline
\end{tabular}

$\overline{\mathrm{x}, \mathrm{y}, \mathrm{z}}$ : Means within columns with different superscripts differ significantly important.

$*: \mathrm{P}<0,05 ; * *: \mathrm{P}<0,01 ; * * *: \mathrm{P}<0,001$

NS: The difference between the mean values is not significant $(\mathrm{P}>0,05)$.

Oo: Oregano oil

\section{Discussion and Conclusion}

In this study the influence of oregano oil additive on the live weights, daily live weight gain averages, feed consumptions and FCR of the lambs was studied and the results are presented in Table-2. Because the study was carried out in summer and the temperature was very high at the time of the trial, all performance values of both control and treatment groups were found lower than expected values. In this study there was not found any statistically significant difference between control and treatment groups regarding the live weight, average daily weight gain, hot carcass weight, hot carcass yield and organ weights (Tables 2 and 3). Similar results have been reported by Bampidis et al. (2) where different doses of oregano leaves (Origanum vulgare L.) were added into the diet of the treatment groups. Other compatible results were seen in the study done with seven month old lambs by Simitzis et al. (20) where oregano oil containing $83,10 \%$ carvacrol and $2,10 \%$ thymol was added into the feed. There was no statistically significant difference between the groups regarding final body weight, live weight gain, hot carcass weight, carcass yield and feed consumption. Chaves et al. (9) reported that adding carvacrol into the diet did not result in any change in live 
weight, dry matter intake and hot carcass weight of the lambs. In another study where Canbolat and Karabulut (7) added oregano oil into urea-enriched diets with different energy and protein levels, no effect on feeding performance and carcass characteristics of the lambs was observed. Previous reports which suggest that essential oils do not have statistically significant importance on the performance of other ruminants, are compatible with the findings of this study $(3,4,14,17,21)$. The results regarding the FCR which were found in oregano oil added groups to be lower in comparison with the rates in control group are consistent with the study findings of Canbolat et al (8). It is believed that this is due to the lipophilic components of carvacrol and thymol in oregano oil, which exert an inhibitory effect on rumen microorganisms. The resulting decrease in the number of bacteria in rumen fluid may restrict fermentation and so may reduce the FCR. However, there are also some reports which suggest that the use of oregano oil in ruminant feeding increases the FCR (3).

In this study, it is considered that the reason for the absence of statistically significant difference between the groups regarding hot carcass weight and carcass yield is, the lack of any influence of oregano oil on the performance parameters such as feed consumption and FCR. In this respect, the results which explain the performance are consistent with each other and with the results from other similar studies $(2,9,20)$. Studies which suggest that essential oil additives have no influence on rumen weights (9) and dried oregano has no influence on intestine weights (2), had similar results with our study concerning the organ weights.

Effects of oregano oil on blood metabolites in lambs have not been investigated widely. Vakili et al. (23) established that thyme essential oil in the diets of feedlot calves $(5 \mathrm{~g} /$ day/calf) resulted in no changes in values of plasma total cholesterol and triglyceride. Whereas in another study it has been reported that, concentrations of trigycerides can be influenced by essential oil supplementation via changing of feed intake (25). In our study, average cholesterol concentration levels were found in the range of 31,58 to $61,50 \mathrm{mg} / \mathrm{dl}$ (Table 4) and were as such within the reference values $(6,16,22)$. Total cholesterol levels of the two treatment groups, decreased and got close to the lower reference value on the $28^{\text {th }}$ day of the trial, however this condition did not continue until the end of the trial. Thus, this parameter was not affected by the addition of the oregano oil. Initial triglyceride levels of the control group was found higher than reference values (12) and it was observed that it decreased below reference values on $28^{\text {th }}$ and $56^{\text {th }}$ days of the trial. It is suggested that the reduction in the serum triglyceride concentration levels was not related with the oregano oil addition, because the triglyceride levels were lower at the end of the trial compared to the beginning in all three groups. In both treatment groups a statistically significant decrease in serum LDL level compared to the levels on other measurement days occurred only on the $28^{\text {th }}$ day of the trial. Because the serum HDL levels were within the reference limits $(10,11,13)$ and there was not any statistically significant difference between the groups, the findings may be interpreted that there was not any effect of oregano oil on aforesaid concentration levels of the lambs.

When the results of this study are assessed overall, it can be said that oregano oil, added into the ration in different doses has no effect on feeding performance and blood values of the lambs, however for a definitive conclusion further studies are needed.

\section{References}

1. AOAC (1994): Official Methods of Analysis, Association of Official Analytical Chemists, Washington DC.

2. Bampidis VA, Christodoulou V, Florou-Paneri P, Christaki E, Spais AB, Chatzopolou PS (2005): Effect of dietary dried oregano leaves supplementation on performance and carcass characteristics of growing lambs. Animal Feed Science and Technology, 121, 285-295.

3. Benchaar C, Duynisveld JL, Charmley E (2006): Effects of monensin and increasing dose levels of a mixture of essential oil compounds on intake, digestion and growth performance of beef cattle. Canadian Journal of Animal Science, 86, 91-96.

4. Benchaar C, Petit HV, Berthiaume R, Oullet DR, Chiquette J, Chouinard PY (2007): Effects of essential oils on digestion, ruminal fermentation, rumen microbial populations, milk production, and milk composition in dairy cows fed alfalfa silage or corn silage. Journal of Dairy Science, 90, 886-897.

5. Benchaar C, Calsamiglia S, Chaves AV, Fraser GR, Colombatto D, McAllister TA, Bauchemin KA (2008): $A$ rewiew of plant-derived essential oils in ruminant nutrition and production. Animal Feed Science and Technology, 145, 209-228.

6. Blood DC, Radostits OM (1989): Veterinary Medicine, A Textbook of Diseases of Cattle, Sheep, Pigs, Goats \& Horses. (7th ed.). U.K.: Bailliere Tindall; London.

7. Canbolat Ö, Karabulut A (2010). Effect of urea and oregano oil supplementation on growth performance and carcass characteristics of lamb fed diets containing different amounts of energy and protein. Turkish Journal of Veterinary and Animal Sciences, 34, 119-128.

8. Canbolat Ö, Karaman Ş, Filya İ (2010): Farklı kekik yă̆ı dozlarının misır silajının sindirimi ve rumen fermantasyonu üzerine etkileri. Kafkas Üniversitesi Veteriner Fakültesi Dergisi, 16, 933-939.

9. Chaves AV, Stanford K, Gibson LL, McAllister TA, Benchaar C (2008): Effects of carvacrol and cinnamaldehyde on intake, rumen fermentation, growth performance, and carcass characteristics of growing lambs. Animal Feed Science and Technology, 145, 396-408.

10. Ellah MRA, Ahmed HM, Mohammed AM, Eltayb AM, Ellah ISA, Elfattah SAA, Rayan AA, Ahmed RM, 
Nagieb NY, Luis MK (2010): Effect of hepatic dysfunction on serum lipoproteins and macroelements status in sheep fascioliasis. The Internet Journal of Veterinary Medicine. 2010 Volume 7 Number 2. DOI: 10.5580/2075

11. Karaalp M, Çimen M (2005): Tüm arpa besisi uygulanan yağlı kuyruklu ve uzun kuyruklu tokluların performanslart ve plazma kolesterol ve lipoprotein düzeylerinin karşılaştırılması. Tarım Bilimleri Dergisi, 11, 129-132.

12. Ketz Riley CJ, Schlerka G, Schuh M, Schusser G, Scope A, Thalhammer J, Tipold A, Vasicek L (2002): Klinisch-chemische Blutuntersuchung. İn: W Baumgartner (Ed), Klinische Propaedeutik der Inneren Krankheiten und Hautkrankheiten der Haus- und Heimtiere. (5th ed). Parey Buchverlag, 231 Berlin.

13. Khaki Z, Khazraiinia P, Chegini S, Nia SK (2010): Comperative study of serum lipid profile in chicken, ostrich, cattle and sheep. İn: P Sibbons (Ed), Comparative Clinical Pathology. Springer-Verlag; 1-5 London.

14. Meyer NF, Erickson GE, Klopfenstein TJ, Greenquist MA, Luebbe MK, Williams P, Engstraom MA (2009): Effect of essential oils, tylosin and monensin on finishing steer performance, carcass characteristics, liver abscesses, ruminal fermentation and digestibility. Journal of Animal Science, 87, 2346-2354.

15. National Research Council (1985): Nutrient Requirements of Sheep. National Academy Press, Washington DC.

16. Nisbet C, Yarım GF, Çiftçi G (2006): Să̆lıklı Karakaya ırkı koyunlara ait bazı serum biyokimyasal değerleri. Ankara Üniversitesi Veteriner Fakültesi Dergisi, 53, 57-59.

17. Offer NW, Bell JF, Roberts DJ (2005): The effect of feeding an essential oil feed additive on dairy cattle performance. BSAS Annual Conference. The British Society of Animal Science. 04-06 April, York.

18. Official Journal of the European Union (2003): Regulation (EC) No 1831/2003 of the European Parliament and of the Council of 22 September 2003 on additives for use in Animal Nutrition. L268/29-L268/43 in OJEU of $10 / 18 / 2003$.
19. Özdamar K (1999): Paket programlar ile istatistiksel veri analizi I. Kaan Kitabevi, Eskişehir.

20. Simitzis PE, Deligeorgis SG, Bizelis JA, Dardamani A, Theodosiou I, Fegeros K (2008): Effect of dietery oregano oil supplementation on lamb meat characteristics. Meat Science, 79, 217-223.

21. Tassoul MD, Shaver RD (2009): Effect of a mixture of supplemental dietary plant essential oils on performance of periparturient and early dairy cows. Journal of Dairy Science, 92, 1734-1740.

22. Toker NY (2004): Gebe koyunlarda ve yeni doğan kuzularda kolesterolün kan serumu ve lipoprotein fraksiyonlarına ait dağılımı. İstanbul Üniversitesi Veteriner Fakültesi Dergisi, 30, 67-74.

23. Vakili AR, Khorrami B, Danesh Mesgaran M, Parand E (2013): The effects of thyme and cinnamon essential oil on performance, rumen fermentation and blood metabolites in Holstein calves consuming high concentrate diet. Asian Australasian Journal of Animal Science, 26, 935-944.

24. Wang CJ, Wang SP, Zhou H (2009): Influences of flavomycin, ropadiar and saponin on nutrient digestibility, rumen fermentation and methane emission from sheep. Animal Feed Science Technology, 148, 157-166.

25. Yang WZ, Ametaj BN, He ML, Benchaar C, Beauchemin KA (2010): Cinnamaldehyde in feedlot cattle diets: intake, growth performance, carcass characteristics, and blood metabolites. Journal of Animal Science, 88, 1082-1092.

Geliş tarihi: 22.11.2013 / Kabul tarihi: 05.03.2014
Address for correspondence:
Dr. Aylin Ünal
Kartal Kimya San. ve Tic. A.Ş.,
Balçık Köyü, Pelitli Yolu Cad., No:140,
41490, Gebze, Kocaeli, Türkiye
e-mail:aylinuenal@yahoo.de 